\title{
利用四重氢键和主客体作用构筑超分子共聚物
}

\author{
肖唐金金 周玲魏小艳李正义孙小强* \\ (常州大学石油化工学院 江苏常州 213164)
}

\begin{abstract}
摘要 合成了一种同时含有腿基嘧啶酮基团(UPy)和苯并 21 冠 7 基团(B21C7)的单体 $\mathbf{H}$ 以及一种同时含有两个二烷基 铵盐单元的单体 $\mathbf{G}$. 分子 $\mathbf{H}$ 和 $\mathbf{G}$ 中的功能基团均由短间隔基相连. $\mathbf{H}$ 可以通过四重氢键形成二聚体，进而和 $\mathbf{G}$ 发生主 客体组装形成线性超分子共聚物. 对该超分子共聚物进行了如下表征：随浓度变化 ${ }^{1} \mathrm{H} N \mathrm{NMR}$, 粘度测试以及扫描电子显 微镜(SEM)等. 该结果将启发在更多领域中利用正交策略构筑各种超分子聚合物智能材料. 关键词 超分子化学; 四重氢键; 自组装; 超分子聚合物; 冠醚; 大环; 主客体作用
\end{abstract}

\section{Supramolecular Copolymers Driven by Quadruple Hydrogen Bonding and Host-Guest Interactions}

\author{
Xiao, Tangxin* Zhou, Ling $\quad$ Wei, Xiaoyan Li, Zhengyi $\quad$ Sun, Xiaoqiang* \\ (School of Petrochemical Engineering, Changzhou University, Changzhou, Jiangsu 213164)
}

\begin{abstract}
A heteroditopic monomer (H) comprised of ureidopyrimidinone (UPy) group and benzo-21-crown-7 motif and a homoditopic monomer $(\mathbf{G})$ containing two dialkylammonium salt units have been successfully prepared. The functional groups both in $\mathbf{H}$ and $\mathbf{G}$ are linked together by a short spacer. Through quadruple hydrogen bonds, $\mathbf{H}$ can self-assemble into dimers, which are capable of complexing with $\mathbf{G}$ via host-guest interaction to form linear supramolecular copolymers. The supramolecular copolymers were fully characterized by various techniques, such as concentration-dependent ${ }^{1} \mathrm{H}$ NMR, viscosity measurements, and scanning electron microscope (SEM). The results will inspire the orthogonal construction of supramolecular polymers for smart materials in more fields.

Keywords supramolecular chemistry; quadruple hydrogen bonds; self-assembly; supramolecular polymer; crown ethers; macrocycles; host-guest interaction
\end{abstract}

\section{Introduction}

In biological systems, many functional biomolecules self-assemble into 3D architectures via multiple non-covalent interactions. For example, DNA employs hydrogen bonding and $\pi-\pi$ stacking interactions to form stable double helix structures. ${ }^{[1 \sim 3]}$ Supramolecular polymers, in which monomeric building blocks are usually hold together by non-covalent interactions, not only show polymer-like properties, but also exhibit many interesting properties, such as stimuli-responsiveness, self-healing and degrada-

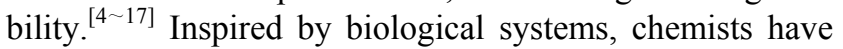
been trying to construct supramolecular polymers by employing two or multiple types of non-covalent interactions, especially in an orthogonal way. ${ }^{[18 \sim 21]}$ For instance, Liu and co-workers developed a supramolecular ternary polymer based on two kinds of host-guest interactions by employing two macrocyclic molecules cucurbit[8]uril and cyclodextrin and a ditopic guest molecule. ${ }^{[22]}$ Huang and co-workers prepared a quadruple-responsive supramolecular gel formed by crown ether based host-guest interaction and Pdbased metal-ligand coordination. ${ }^{[23]}$ Recently, Yin, Stang, and co-workers reported a fluorescent metallacage-cored supramolecular network gel, which assembled by orthogonal host-guest interaction and metal coordination. ${ }^{[24]} \mathrm{Be}-$ sides these examples, various supramolecular complexes fabricated by multiple orthogonal non-covalent interactions have been reported in recent years. ${ }^{[25 ~ 30]}$ As we know, short spacer may endow supramolecular polymers with special properties. However, in the previous reports, functional groups in the monomer are usually linked together by long alkyl chain. ${ }^{[31 \sim 33]}$ In this paper, the construction of supramolecular polymers was reported by employing two dif-

* Corresponding authors. E-mail: xiaotangxin@cczu.edu.cn; xqsun@cczu.edu.cn

Received November 7, 2019; revised November 30, 2019; published online December 19, 2019.

Project supported by the National Natural Science Foundation of China (Nos. 21702020, 21572026).

国家自然科学基金(Nos. 21702020, 21572026)资助项目 
ferent monomers containing short spacers.

UPy-based quadruple hydrogen bonding interaction, first disclosed by Meijer and co-workers, has gained much attention in the area of supramolecular materials on accounts of its strong dimerization constant and synthetic simplicity. ${ }^{[34,35]}$ Since then, a large number of functional supramolecular polymers have been prepared based on UPy. ${ }^{[36 \sim 46]}$ Dialkylammonium salts could be efficiently complexed with benzo-21-crown-7 (B21C7), which was developed by Huang and co-workers. ${ }^{[47 \sim 49]}$ B21C7 has been used to construct self-sorting systems and supramolecular polymers. ${ }^{[50 \sim 53]}$ We have been endeavored to study various non-covalent interactions in supramolecular chemistry. ${ }^{[54 \sim 59]}$ Herein, we report a linear supramolecular polymer constructed by orthogonal quadruple hydrogen bonding and host-guest interactions, which was realized by employing two types of monomers, UPy-functionalized B21C7 (H) and homoditopic secondary ammonium salt molecule $(\mathbf{G})$ (Figure 1). Firstly, $\mathbf{H}$ forms a dimer via quadruple hydrogen bonding in a mixed $\mathrm{CHCl}_{3} / \mathrm{CH}_{3} \mathrm{CN}(V: V=1: 1)$ solvent. Secondly, a linear supramolecular polymer could be obtained upon the addition of $\mathbf{G}$.

\section{Results and discussion}

The monomers $\mathbf{G}$ and $\mathbf{H}$ were well-designed and successfully synthesized. The UPy motif in $\mathbf{H}$ was directly connected to the benzene group of B21C7. The UPy unit endows the monomer with the ability to self-dimerize via quadruple hydrogen bonds, while $\mathrm{B} 21 \mathrm{C} 7$ provides a macrocycle to further complex with $\mathbf{G}$ via host-guest interaction. The synthetic process of $\mathbf{G}$ and $\mathbf{H}$ is shown in Scheme 1. Starting from fluorenone, compound $\mathbf{1}$ is prepared and further converted to compound $\mathbf{2}$ in toluene solution by reacting with 4-formylphenylboronic acid through Suzuki reaction. Finally, compound 2 reacts with $n$-butylamine to afford dialkylammonium G. Hexa(ethyleneglycol)dittosylate condenses with 4-nitrobenzene-1,2-diol to produce crown ether $\mathbf{3}$, which can be further reduced to compound 4 . Coupling 4 with 1,1'-carbonyldiimidazole activated pyrimidinone $\mathbf{M}$ results in the host molecule $\mathbf{H}$. $\mathbf{G}$ and $\mathbf{H}$ were fully characterized by ${ }^{1} \mathrm{H}$ NMR, ${ }^{13} \mathrm{C}$ NMR and HR-MS. ${ }^{1} \mathrm{H}-{ }^{1} \mathrm{H}$ COSY NMR was employed to assist the assignment of protons in compound $\mathbf{H}$. Moreover, a host-guest complex was evidenced by HR-MS.

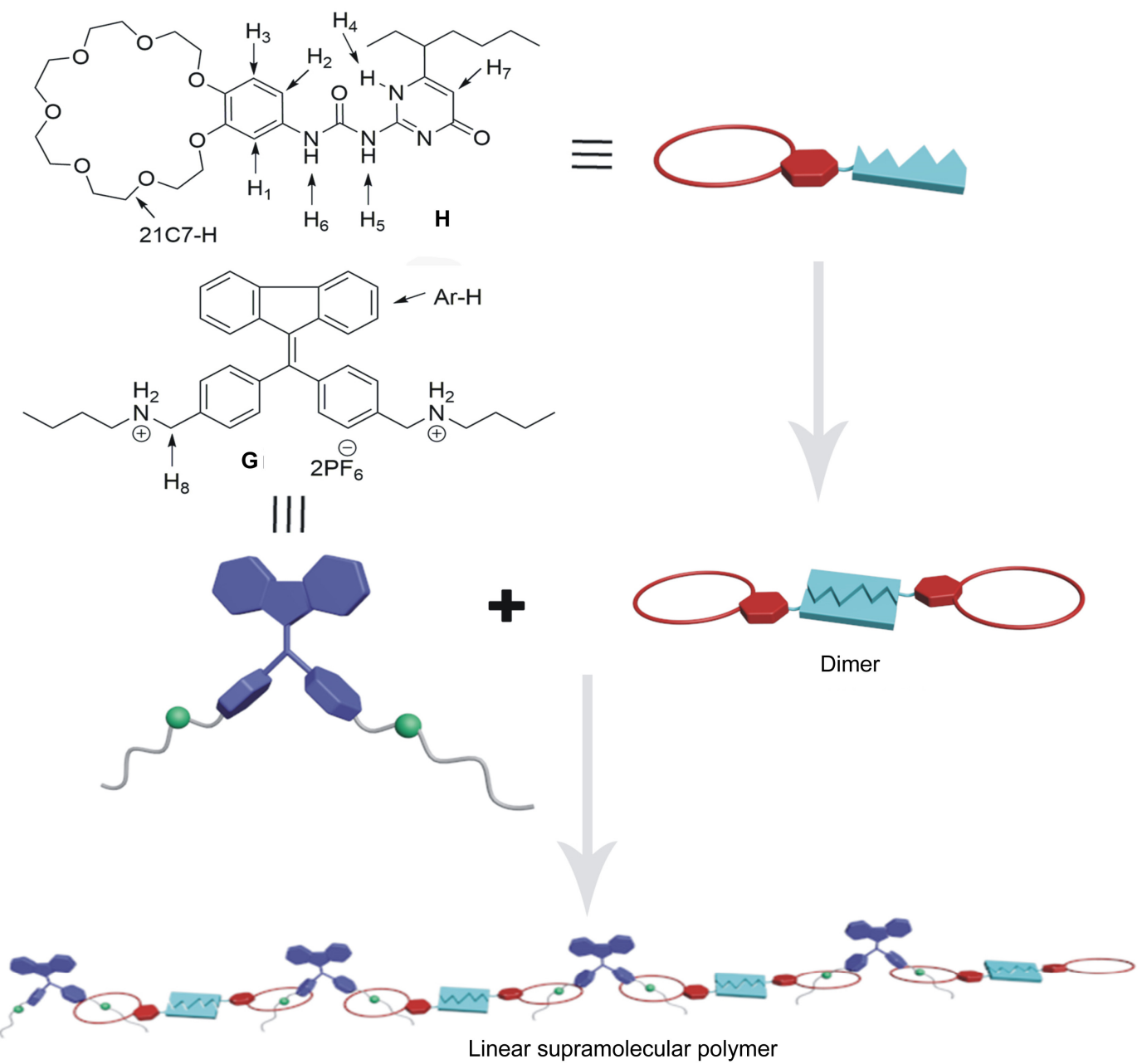

Figure 1 Cartoon representation of the construction of linear supramolecular polymer from two different monomers by orthogonal self-assembly 


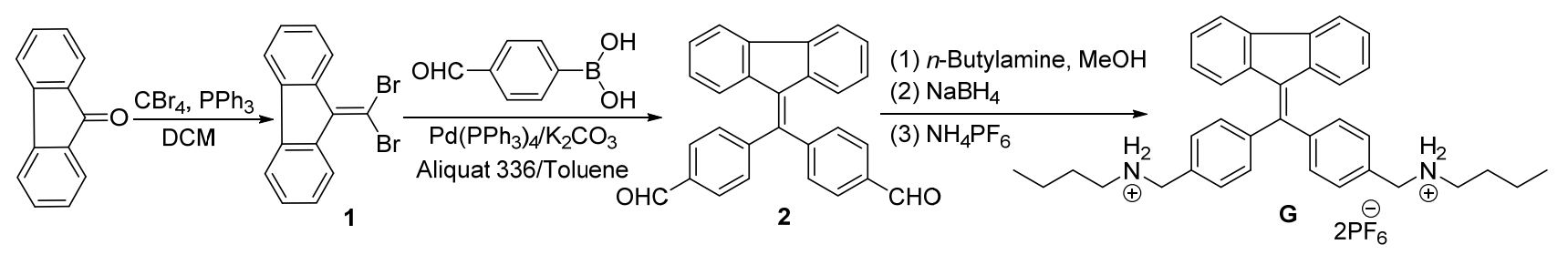

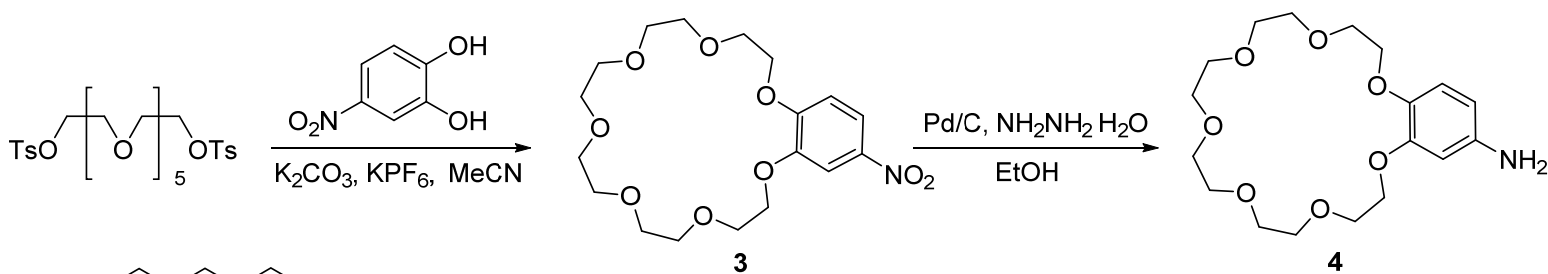<smiles>CCCCC(CC)c1cc(=O)nc(NC(=O)n2ccnc2)n1C</smiles><smiles>CCCCC(CC)c1cc(=O)nc(NC(=O)Nc2ccc3c(c2)OCCOCCOCCOCCOCCOCC3)[nH]1</smiles>

Scheme 1 Synthetic routes for $\mathbf{G}$ and $\mathbf{H}$

The formation of linear supramolecular polymers was first investigated by concentration-dependent ${ }^{1} \mathrm{H}$ NMR, which was recorded in $\mathrm{CDCl}_{3} / \mathrm{CD}_{3} \mathrm{CN}(V: V=1: 1)$ at concentrations in the range of $8 \sim 128 \mathrm{mmol} / \mathrm{L}$ (Figure 2). The UPy $\mathrm{N}-H$ peaks in mixed $\mathrm{CDCl}_{3} / \mathrm{CD}_{3} \mathrm{CN}$ solvents showed large downfield shifts (between $\delta 9$ and 13.5), giving direct evidence for the dimerization. Upon the addition of $\mathbf{G}$, these peaks still showed large downfield shifts, indicating the orthogonal properties of quadruple hydrogen bonding and host-guest interactions in this system. The benzyl protons $(\delta 4.21)$ and two of the aryl protons $(\delta 6.48)$ in $\mathbf{G}$ and protons in crown ether of $\mathbf{H}(\delta 4.20 \sim 3.50)$ showed obvious down field shifts, indicating the strong

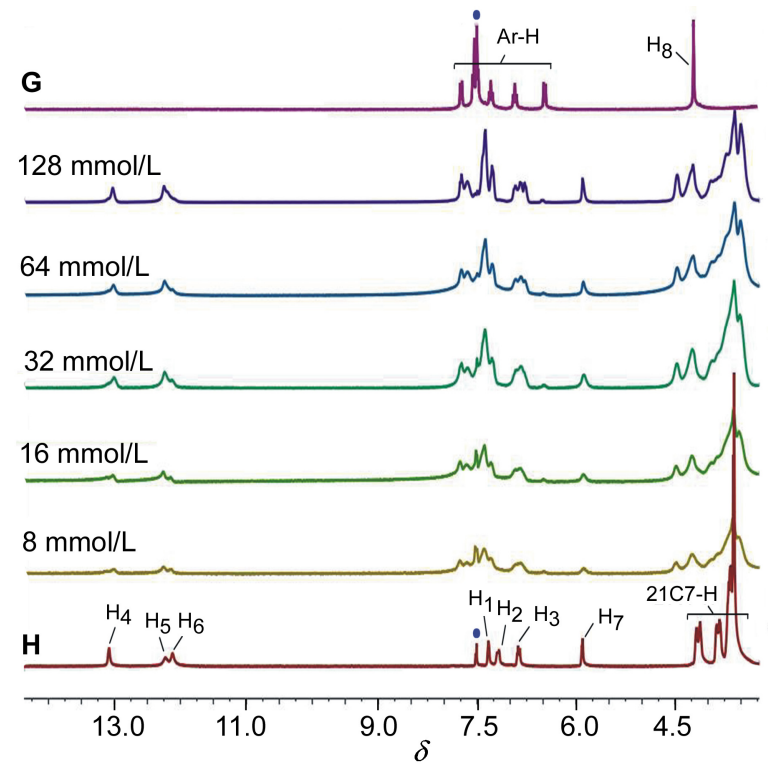

Figure 2 Partial ${ }^{1} \mathrm{H}$ NMR spectra $\left(300 \mathrm{MHz}, \mathrm{CDCl}_{3} / \mathrm{CD}_{3} \mathrm{CN}\right.$, $V: V=1: 1,298 \mathrm{~K}$ ) of $\mathbf{H}$; mixtures of $\mathbf{H}$ and 0.50 equiv. $\mathbf{G}$ at different $\mathbf{H}$ concentrations: 8, 16, 32, 64 and $128 \mathrm{mmol} / \mathrm{L}$; and $\mathbf{G}$ The blue dots indicate solvent peaks host-guest complexation between $\mathbf{G}$ and $\mathbf{H}$. Moreover, all the proton peaks became broad as the concentration increases, offering evidence for the generation of highmolecular-weight assemblies driven by orthogonal quadruple hydrogen bonding and host-guest interactions.

To further study the supramolecular polymers driven by orthogonal self-assembly, viscosity experiments were performed in mixed $\mathrm{CDCl}_{3} / \mathrm{CD}_{3} \mathrm{CN}$ solvents $(V: V=1: 1)$ by employing a micro-Ubbelohde viscometer. A double logarithmic plot of specific viscosity versus concentration was depicted in Figure 3, which displays a critical polymerrization concentration (CPC) at about $51 \mathrm{~g} / \mathrm{L}$ of $\mathbf{H}$ concentration. A slope of 1.01 was found in the initial stage as the concentration increases, which is a feature of cyclic species with constant size. ${ }^{[35]}$ In this study, we speculated that a cyclic oligomer composing two $\mathbf{H}$ dimers and two $\mathbf{G}$ molecules could be formed below CPC. Of course, besides this smallest one, larger cyclic oligomer composing more $\mathbf{H}$ dimers and $\mathbf{G}$ may also exist. The slope was turned to 2.45

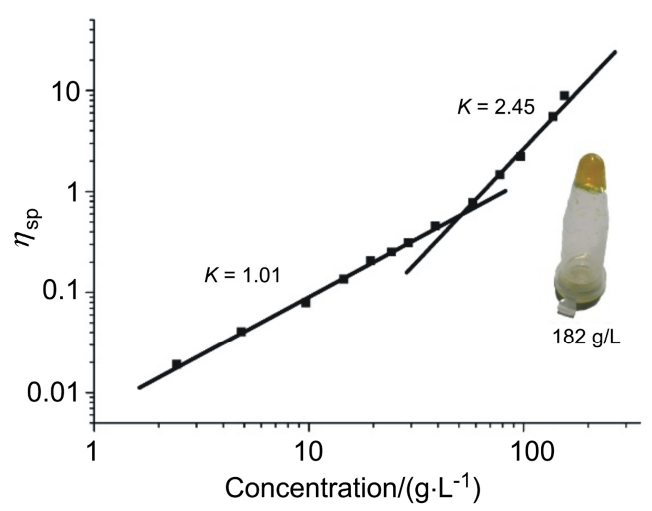

Figure 3 Specific viscosity of $\mathbf{H}$ with 0.5 equiv. of $\mathbf{G}$ vs. the $\mathbf{H}$ concentration in $\mathrm{CDCl}_{3} / \mathrm{CD}_{3} \mathrm{CN}(V: V=1: 1)$ solutions $(298 \mathrm{~K})$ Inset: a concentrated solution of $\mathbf{G}$ and $\mathbf{H}$ 
when the concentration was above CPC, suggesting the transition of assemblies from cyclic oligomers to supramolecular copolymers with increasing size. The slope value is similar to the value obtained for supramolecular polymers constructed from homoditopic building blocks comprised of bis-B21C7-based AA monomer and bis(dialkylammonium salt)-based BB monomer, indicating that the quadruple hydrogen bonding in UPy dimers has little affection on the properties of such types of supramolecular polymers. ${ }^{[60]}$

Further direct evidence for the formation of supramolecular copolymers was obtained by scanning electron microscope (SEM). Rod-like fiber could be drawn from a concentrated solution of $\mathbf{G}$ and $\mathbf{H}$ (molar ratio $\mathbf{G} / \mathbf{H}=1 / 2$ ). Such fibers could be only formed by entanglement of linearly connected large aggregates. By contrast, no fibers could be pulled out from the single concentrated solution of the quadruply hydrogen bonded $\mathbf{H}$ dimer or the solution of individual $\mathbf{G}$ molecule. Since the rigid spacer in $\mathbf{G}$ is a polycyclic aromatic hydro-carbon group, we envisioned whether the supramolecular polymers possess fluorescent property. However, the fluorescence test showed that the supramolecular polymer had no fluorescence. This might be due to that the two dialkylammonium groups at both ends quench the fluorescence.

Due to the strong binding property of B21C7 group and $\mathrm{K}^{+}$, the reversibility of the obtained supramolecular polymers upon addition/removal of a competitive $\mathrm{K}^{+}$was investigated by viscosity measurement (Figure 4). When 1 equiv. of $\mathrm{KPF}_{6}$ was added to a solution of $\mathbf{H}(78 \mathrm{~g} / \mathrm{L})$ with 0.5 equiv. of $\mathbf{G}$ in mixed $\mathrm{CHCl}_{3} / \mathrm{CH}_{3} \mathrm{CN}(V: V=1: 1)$ solution, the $\mathrm{K}^{+}$was placed into the $\mathrm{B} 21 \mathrm{C} 7 \mathrm{ring}$ of $\mathbf{H}$, pushing the dialkylammoniun salt to slide out of the cavity of B21C7 owing to its stronger binding affinity to $\mathrm{K}^{+}$. At this time, the dramatic decrease of specific viscosity was observed due to the disassembly of the linear supramolecular polymer. After 1 equiv. of benzo-18-crown-6 (B18C6) was subsequently added to the above solution, the specific viscosity was increased largely, indicating that the supramolecular polymer was reformed due to the stronger complexation of $\mathrm{K}^{+}$with $\mathrm{B} 18 \mathrm{C} 6$. This process was repeated for one more time and similar result was observed, indicating

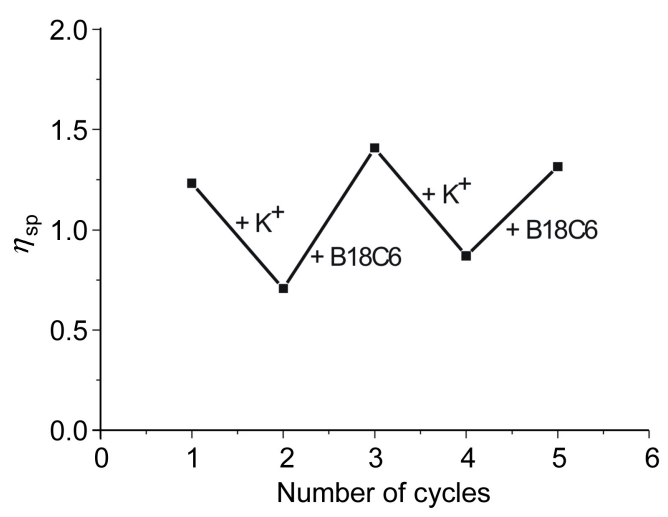

Figure 4 Specific viscosity of a solution of supramolecular polymer constructed from $\mathbf{H}$ and $\mathbf{G}$ upon stepwise addition of equal equiv. of $\mathrm{K}^{+}$ion or B18C6 that the quadruple hydrogen bonding interaction was orthogonal to the host-guest interaction.

\section{Conclusions}

In conclusion, we have designed and successfully synthesized two different monomers comprised of B21C7, UPy, and dialkylammonium units. We further demonstrated that linear supramolecular copolymers could be fabricated from such two monomers by orthogonal quadruple hydrogen bonding and host-guest interactions. By employing combination of techniques, such as concentration-dependent ${ }^{1} \mathrm{H}$ NMR, ${ }^{1} \mathrm{H}-{ }^{1} \mathrm{H}$ COSY, SEM, and viscosity measurements, the supramolecular polymers were fully characterized. Moreover, such supramolecular polymers displayed stimuli-responsive capability, and their reversibility could be orthogonally switched by addition or removal of $\mathrm{K}^{+}$ without disruption of quadruple hydrogen bonding. Our future work will focus on developing fluorescent supramolecular copolymers driven by orthogonal self-assembly.

\section{Experimental}

\subsection{Materials and instruments}

The commercially available reagents and solvents were either employed as purchased or dried according to procedures described in the literature. Compounds $\mathbf{1}^{[61]}$ $\mathbf{4}^{[62]}$ and $\mathbf{M}^{[63]}$ were prepared according to literature procedure. All yields were given as isolated yields. NMR spectra were recorded on a Bruker DPX $300 \mathrm{MHz}$ spectrometer with internal standard tetramethylsilane (TMS) and solvent signals as internal references, where $\mathrm{CDCl}_{3}$ and $\mathrm{CD}_{3} \mathrm{CN}$ were dried using neutral aluminium oxide. ${ }^{1} \mathrm{H}-{ }^{1} \mathrm{H}$ COSY experiments were performed on a Bruker AVANCE III $300 \mathrm{MHz}$ spectrometer. Low-resolution electrospray ionization mass spectra (LR-ESI-MS) were obtained on LCMS2020. High-resolution electrospray ionization mass spectra (HR-ESI-MS) were recorded on an Agilent Technologies 6540 UHD Accurate-Mass. Scanning electron microscopy (SEM) image were recorded on a JSM-6360LA. Viscosity measurements were carried out with a Ubbelohde micro viscometer (Shanghai Liangjing Glass Instrument Factory, $0.40 \mathrm{~mm}$ inner diameter) at $298 \mathrm{~K}$ in chloroform/acetonitrile $(V: V=1: 1)$.

\subsection{Synthesis of 9 -(dibromomethylene)-9H-fluorene}

Fluorenone (1.80 g, $10.0 \mathrm{mmol})$, carbon tetrabromide (6.63 g, $20.0 \mathrm{mmol})$, and triphenyl phosphine (10.49 g, 40.0 $\mathrm{mmol})$ were combined in $50 \mathrm{~mL}$ of anhydrous dichloromethane. The reaction was run at $40{ }^{\circ} \mathrm{C}$ for $24 \mathrm{~h}$. Column chromatography of the crude product on silica gel with hexanes as the eluent gave yellow solid, followed by recrystallization from hexane to provide $1(1.40 \mathrm{~g}, 42 \%)$ as yellow crystals. m.p. $134 \sim 136{ }^{\circ} \mathrm{C}$ (lit. ${ }^{[64]}$ m.p. $128 \sim$ $\left.130{ }^{\circ} \mathrm{C}\right) ;{ }^{1} \mathrm{H}$ NMR $\left(300 \mathrm{MHz}, \mathrm{CDCl}_{3}\right) \delta: 8.61(\mathrm{~d}, J=8.0$ $\mathrm{Hz}, 2 \mathrm{H}), 7.68$ (d, $J=7.4 \mathrm{~Hz}, 2 \mathrm{H}), 7.42(\mathrm{td}, J=7.4,0.9 \mathrm{~Hz}$, $2 \mathrm{H}), 7.31(\mathrm{td}, J=8.0,1.2 \mathrm{~Hz}, 2 \mathrm{H})$. 
4.3 Synthesis of 4,4'-((9H-fluoren-9-ylidene)methylene)dibenzaldehyde (2)

4-Formylphenylboronic acid $(1.30 \mathrm{~g}, 9.0 \mathrm{mmol})$ and $\mathbf{1}$ $(1.00 \mathrm{~g}, 3.0 \mathrm{mmol})$ were dissolved in $30 \mathrm{~mL}$ of toluene, and then $2 \mathrm{~mol} / \mathrm{L}$ aqueous $\mathrm{K}_{2} \mathrm{CO}_{3}$ solution $(4.5 \mathrm{~mL})$ and aliquat $336(0.36 \mathrm{~g}, 0.9 \mathrm{mmol})$ were added. The mixture was stirred for $0.5 \mathrm{~h}$ under $\mathrm{N}_{2}$ atmosphere at room temperature. Then $\mathrm{Pd}\left(\mathrm{PPh}_{3}\right)_{4}(0.34 \mathrm{~g}, 0.3 \mathrm{mmol})$ catalyst was added and the reaction mixture was stirred at $80{ }^{\circ} \mathrm{C}$ for $16 \mathrm{~h}$. After cooling to room temperature, the product was concentrated and purified by silica gel column chromatography with dichloromethane $/ n$-hexane $(V: V=2: 1)$ to provide $2(1.11$ g, 96\%) as yellow solid. m.p. $202 \sim 203{ }^{\circ} \mathrm{C} ;{ }^{1} \mathrm{H}$ NMR (300 $\left.\mathrm{MHz}, \mathrm{CDCl}_{3}\right) \delta: 10.09(\mathrm{~s}, 2 \mathrm{H}), 7.96(\mathrm{~d}, J=8.3 \mathrm{~Hz}, 4 \mathrm{H}), 7.69$ (d, $J=7.5 \mathrm{~Hz}, 2 \mathrm{H}), 7.57(\mathrm{~d}, J=8.1 \mathrm{~Hz}, 4 \mathrm{H}), 7.28(\mathrm{dt}, J=$ $7.4,0.9 \mathrm{~Hz}, 2 \mathrm{H}), 6.99 \sim 6.88(\mathrm{~m}, 2 \mathrm{H}), 6.59(\mathrm{~d}, J=7.9 \mathrm{~Hz}$, $2 \mathrm{H}) ;{ }^{13} \mathrm{C}$ NMR $\left(75 \mathrm{MHz}, \mathrm{CDCl}_{3}\right) \delta: 191.75,148.28,141.27$, $140.98,137.77,136.38,136.03,130.60,130.42,128.75$, $126.83,125.00,119.66$. HR-ESI-MS calcd for $\mathrm{C}_{28} \mathrm{H}_{19} \mathrm{O}_{2}$ $[\mathrm{M}+\mathrm{H}]^{+}$387.1385, found 387.1394.

4.4 Synthesis of $N, N^{\prime}-((((9 H$-fluoren-9-ylidene)methylene)bis(4,1-phenylene))bis(methylene))bisbutylammonium bis(hexafluorophosphate) $(\mathrm{G})$

Compound $2(0.93 \mathrm{~g}, 2.4 \mathrm{mmol})$ and $n$-butylamine $(0.70 \mathrm{~g}, 9.6 \mathrm{mmol})$ were dissolved in methanol $(100 \mathrm{~mL})$ and stirred at $70{ }^{\circ} \mathrm{C}$ under $\mathrm{N}_{2}$ atmosphere overnight. After the reaction mixture was cooled to ambient temperature, $\mathrm{NaBH}_{4}(0.36 \mathrm{~g}, 9.6 \mathrm{mmol})$ was added to the solution in small portions and the mixture was stirred at room temperature for another $12 \mathrm{~h}$. Water was added to quench the remaining $\mathrm{NaBH}_{4}$ and $2.4 \mathrm{~mol} / \mathrm{L} \mathrm{HCl}$ was added to acidify the amine. The solvent was removed to give a white solid which was dissolved in deionized water/methanol $(500 \mathrm{~mL}, V$ : $V=5: 1)$. A saturated aqueous solution of $\mathrm{NH}_{4} \mathrm{PF}_{6}$ was added to afford white precipitate which was filtered off and washed with deionized water to afford $\mathbf{G}(1.2 \mathrm{~g}, 63 \%)$ as white solid. m.p. $257 \sim 259{ }^{\circ} \mathrm{C} ;{ }^{1} \mathrm{H}$ NMR $(300 \mathrm{MHz}$, $\left.\mathrm{CD}_{3} \mathrm{CN}\right) \delta: 7.82(\mathrm{~d}, J=7.5 \mathrm{~Hz}, 2 \mathrm{H}), 7.66 \sim 7.49(\mathrm{~m}, 8 \mathrm{H})$, $7.34(\mathrm{td}, J=7.5,0.9 \mathrm{~Hz}, 2 \mathrm{H}), 7.02 \sim 6.93(\mathrm{~m}, 2 \mathrm{H}), 6.48(\mathrm{~d}$, $J=7.9 \mathrm{~Hz}, 2 \mathrm{H}), 4.26(\mathrm{~s}, 4 \mathrm{H}), 3.17 \sim 3.04(\mathrm{~m}, 4 \mathrm{H}), 1.79 \sim$ $1.63(\mathrm{~m}, 4 \mathrm{H}), 1.51 \sim 1.40(\mathrm{~m}, 4 \mathrm{H}), 0.99(\mathrm{t}, J=7.3 \mathrm{~Hz}, 6 \mathrm{H})$; ${ }^{13} \mathrm{C}$ NMR $\left(75 \mathrm{MHz}, \mathrm{CD}_{3} \mathrm{CN}\right) \delta: 144.45,143.72,141.10$, $138.53,135.30,131.64,131.36,129.96,129.02,127.25$, $125.31,120.29,51.82,48.45,28.14,19.90,13.31$; ESI-MS calcd for $\left[\mathrm{M}-\mathrm{PF}_{6}\right]^{+}$647.30, found 647.10; HR-ESI-MS $\left(\mathrm{C}_{36} \mathrm{H}_{42} \mathrm{~F}_{12} \mathrm{~N}_{2} \mathrm{P}_{2}\right)$ calcd for $\left[\mathrm{M}-\mathrm{PF}_{6}\right]^{+}$647. 2984, found 647.2979 .

\subsection{Synthesis of 3-nitrobenzo-21-crown ether (3)}

A mixture of hexa(ethyleneglycol)ditosylate $(1.00 \mathrm{~g}$, $1.7 \mathrm{mmol})$, 4-nitrobenzene-1,2-diol $(0.26 \mathrm{~g}, 1.7 \mathrm{mmol})$, $\mathrm{K}_{2} \mathrm{CO}_{3}(0.47 \mathrm{~g}, 2.5 \mathrm{mmol})$, and $\mathrm{KPF}_{6}(0.71 \mathrm{~g}, 5.1 \mathrm{mmol})$ in $25 \mathrm{~mL}$ of $\mathrm{CH}_{3} \mathrm{CN}$ was stirred and refluxed for $12 \mathrm{~h}$ under nitrogen gas protection. After cooling, the mixture was filtered and $\mathrm{CH}_{3} \mathrm{CN}$ was removed with a rotary evaporator, and then $\mathrm{CH}_{2} \mathrm{Cl}_{2}$ was added. After washing with water $(20$ $\mathrm{mL} \times 3)$ and brine $(30 \mathrm{~mL} \times 3)$, the organic phase was dried with $\mathrm{Na}_{2} \mathrm{SO}_{4}$ and then concentrated. The product was used in the next step without further purification.

\subsection{Synthesis of 3-aminobenzo-21-crown ether (4)}

Compound $3(0.78 \mathrm{~g}, 1.9 \mathrm{mmol})$ and $10 \% \mathrm{Pd} / \mathrm{C}(10$ $\mathrm{mg}$ ) were mixed in $20 \mathrm{~mL}$ of degassed ethanol under argon atmosphere and degassed hydrazine monohydrate $(0.95 \mathrm{~g}$, $19.0 \mathrm{mmol}$ ) was added to the mixture which was heated at $80{ }^{\circ} \mathrm{C}$ in the dark for $1 \mathrm{~h}$. The mixture was filtered quickly through Celite while hot, the filtrate was evaporated under reduced pressure and the residue was purified by silica gel flash column chromatography (PE/EA, $V: V=3: 1,5 \%$ $\left.\mathrm{Et}_{3} \mathrm{~N}\right)$ to provide $4^{[62]}(0.37 \mathrm{~g}, 51 \%)$ as yellow oil. ${ }^{1} \mathrm{H}$ NMR $\left(300 \mathrm{MHz}, \mathrm{CDCl}_{3}\right) \delta: 6.70(\mathrm{~d}, J=8.4 \mathrm{~Hz}, 1 \mathrm{H}), 6.25(\mathrm{~d}, J=$ $2.6 \mathrm{~Hz}, 1 \mathrm{H}), 6.18(\mathrm{dd}, J=8.4,2.6 \mathrm{~Hz}, 1 \mathrm{H}), 4.09 \sim 4.02(\mathrm{~m}$, $4 \mathrm{H}), 3.88 \sim 3.82(\mathrm{~m}, 4 \mathrm{H}), 3.76 \sim 3.63(\mathrm{~m}, 16 \mathrm{H})$.

\subsection{Synthesis of ureidopyrimidinone derived benzo-} 21-crown ether $(\mathrm{H})$

Imidazolide $\mathbf{M}(81.00 \mathrm{mg}, 0.27 \mathrm{mmol})$ and $4(0.10 \mathrm{~g}$, $0.27 \mathrm{mmol}$ ) were dissolved in $15 \mathrm{~mL}$ of dry $\mathrm{CHCl}_{3}$ and this solution was stirred for $12 \mathrm{~h}$ under nitrogen at room temperature. To the reaction mixture $50 \mathrm{~mL}$ of $\mathrm{CHCl}_{3}$ was added and the organic layer was washed with $1 \mathrm{~mol} / \mathrm{L} \mathrm{HCl}$ $(30 \mathrm{~mL})$, saturated $\mathrm{NaHCO}_{3}(30 \mathrm{~mL})$, brine $(30 \mathrm{~mL})$ and dried over $\mathrm{Na}_{2} \mathrm{SO}_{4}$. After the solvent was removed, the resulting residue was subjected to column chromatography $\mathrm{CH}_{2} \mathrm{Cl}_{2} / \mathrm{MeOH}(V: V=100: 1)$ to give $\mathbf{H}(0.12 \mathrm{~g}, 73 \%)$ as yellowish solid. m.p. $163 \sim 164{ }^{\circ} \mathrm{C} ;{ }^{1} \mathrm{H}$ NMR $(300 \mathrm{MHz}$, $\left.\mathrm{CDCl}_{3}\right) \delta: 13.11(\mathrm{~s}, 1 \mathrm{H}), 12.25(\mathrm{~s}, 1 \mathrm{H}), 12.08(\mathrm{~s}, 1 \mathrm{H}), 7.31$ $(\mathrm{d}, J=2.4 \mathrm{~Hz}, 1 \mathrm{H}), 7.16(\mathrm{dd}, J=8.7,2.3 \mathrm{~Hz}, 1 \mathrm{H}), 6.86(\mathrm{~d}$, $J=8.7 \mathrm{~Hz}, 1 \mathrm{H}), 5.90(\mathrm{~s}, 1 \mathrm{H}), 4.24 \sim 4.12(\mathrm{~m}, 4 \mathrm{H}), 3.97 \sim$ $3.88(\mathrm{~m}, 4 \mathrm{H}), 3.82 \sim 3.64(\mathrm{~m}, 16 \mathrm{H}), 2.38 \sim 2.29(\mathrm{~m}, 1 \mathrm{H})$, $1.73 \sim 1.52(\mathrm{~m}, 4 \mathrm{H}), 1.31 \sim 1.20(\mathrm{~m}, 4 \mathrm{H}), 0.94 \sim 0.84(\mathrm{~m}$, $6 \mathrm{H}) ;{ }^{13} \mathrm{C} \mathrm{NMR}\left(75 \mathrm{MHz}, \mathrm{CDCl}_{3}\right) \delta: 173.05,155.76,154.81$, $154.75,149.15,145.58,132.00,115.12,113.86,108.20$, $106.54,71.17,71.13,71.08,71.05(2 \mathrm{C}), 70.98,70.58(2 \mathrm{C})$, $69.86,69.78,69.74,69.22,45.48,32.95,29.36,26.67$, 22.50, 13.91, 11.74; ESI-MS $m / z: 629.10[\mathrm{M}+\mathrm{Na}]^{+}$; HR-ESI-MS calcd for $\mathrm{C}_{30} \mathrm{H}_{47} \mathrm{~N}_{4} \mathrm{O}_{9}[\mathrm{M}+\mathrm{H}]^{+}$607.3343, found 607.3338 .

Supporting Information ${ }^{1} \mathrm{H}$ NMR, ${ }^{13} \mathrm{C}$ NMR, and HR-MS spectra of compounds $\mathbf{1}, \mathbf{2}, \mathbf{4}, \mathbf{H}$ and $\mathbf{G} ;{ }^{1} \mathrm{H}-{ }^{1} \mathrm{H}$ COSY of $\mathbf{H}$; SEM micrograph of $\mathbf{H}$ and $\mathbf{G}$ complex; HRMS of complexes $\mathbf{H}$ and $\mathbf{G}$. The Supporting Information is available free of charge via the Internet at http://siocjournal.cn.

\section{References}

[1] Bandy, T. J.; Brewer, A.; Burns, J. R.; Marth, G.; Nguyen, T.; Stulz, E. Chem. Soc. Rev. 2011, 40, 138

[2] McLaughlin, C. K.; Hamblin, G. D.; Sleiman, H. F. Chem. Soc. Rev. 2011, 40, 5647.

[3] Watson, J. D.; Crick, F. H. C. Nature 1953, 171, 737.

[4] Goor, O. J. G. M.; Hendrikse, S. I. S.; Dankers, P. Y. W.; Meijer, E. W. Chem. Soc. Rev. 2017, 46, 6621.

[5] Würthner, F.; Saha-Möller, C. R.; Fimmel, B.; Ogi, S.; Leowanawat, P.; Schmidt, D. Chem. Rev. 2016, 116, 962. 
[6] Yang, L.; Tan, X.; Wang, Z.; Zhang, X. Chem. Rev. 2015, 115, 7196.

[7] Ma, X.; Tian, H. Acc. Chem. Res. 2014, 47, 1971.

[8] Yan, X.; Wang, F.; Zheng, B.; Huang, F. Chem. Soc. Rev. 2012, 41, 6042.

[9] Brunsveld, L.; Folmer, B. J.; Meijer, E. W.; Sijbesma, R. P. Chem. Rev. 2001, 101, 4071.

[10] Li, B.; Wang, B.; Huang, X.; Dai, L.; Cui, L.; Li, J.; Jia, X.; Li, C. Angew. Chem., Int. Ed. 2019, 58, 3885.

[11] Li, M, Han, K, Li, J, Jia X, Li C. Acta Polym. Sin. 2017, 129 (in Chinese). (李明阳，韩康，李健，贾学顺，李春举，高分子学报, 2017, 129.)

[12] Zheng, B.; Hou, Y.; Gao, L.; Zhang, M. Chin. J. Chem. 2019, 37, 843.

[13] Zhao, Y.-K.; Gao, Z.-Z.; Wang, H.; Zhang, D.-W.; Li, Z.-T. Chin. Chem. Lett. 2019, 30, 127.

[14] Chen, Y.; Sun, S.; Lu, D.; Shi, Y.; Yao, Y. Chin. Chem. Lett. 2019, 30, 37.

[15] Yin, G.; Chen, L.; Wang, C.; Yang, H. Chin. J. Chem. 2018, 36, 134.

[16] Xu, C.; Xu, L.; Ma, X. Chin. Chem. Lett. 2018, 29, 970.

[17] Wang, X.; Yang, Y.; Fan, L.; Yang, F.; Wu, D. Sci. China Chem. 2018, 61,311.

[18] Xiao, T.; Zhou, L.; Sun, X.-Q.; Huang, F.; Lin, C.; Wang, L. Chin. Chem. Lett. 2020, 31, 1.

[19] Wei, P.; Yan, X.; Huang, F. Chem. Soc. Rev. 2015, 44, 815.

[20] Elacqua, E.; Lye, D. S.; Weck, M. Acc. Chem. Res. 2014, 47, 2405.

[21] Li, S.-L.; Xiao, T.; Lin, C.; Wang, L. Chem. Soc. Rev. 2012, 41, 5950.

[22] Wang, Q.; Chen, Y.; Liu, Y. Polym. Chem. 2013, 4, 4192.

[23] Yan, X.; Xu, D.; Chi, X.; Chen, J.; Dong, S.; Ding, X.; Yu, Y.; Huang, F. Adv. Mater. 2012, 24, 362.

[24] Lu, C.; Zhang, M.; Tang, D.; Yan, X.; Zhang, Z.; Zhou, Z.; Song, B.; Wang, H.; Li, X.; Yin, S.; Sepehrpour, H.; Stang, P. J. J. Am. Chem. Soc. 2018, 140, 7674.

[25] Zhang, Z.; Liu, Y.; Zhao, J.; Yan, X. Polym. Chem. 2019, 11, 367.

[26] Wang, Q.; Cheng, M.; Tian, L.; Fan, Q.; Jiang, J. Polym. Chem. 2017, 8, 6058 .

[27] Kim, D. S.; Chang, J.; Leem, S.; Park, J. S.; Thordarson, P.; Sessler, J. L. J. Am. Chem. Soc. 2015, 137, 16038.

[28] Hu, X.-Y.; Zhang, P.; Wu, X.; Xia, W.; Xiao, T.; Jiang, J.; Lin, C.; Wang, L. Polym. Chem. 2012, 3, 3060 .

[29] Guan, Y.; Ni, M.; Hu, X.; Xiao, T.; Xiong, S.; Lin, C.; Wang, L. Chem. Comm. 2012, 48, 8529.

[30] Li, S.-L.; Xiao, T.; Wu, Y.; Jiang, J.; Wang, L. Chem. Commun. 2011, 47, 6903.

[31] Xu, L. N.; Chen, D.; Zhang, Q.; He, T.; Lu, C. J.; Shen, X.; Tang, D. T.; Qiu, H. Y.; Zhang, M. M.; Yin, S. C. Polym. Chem. 2018, 9 , 399.

[32] Shangguan, L.; Xing, H.; Mondal, J. H.; Shi, B. Chem. Commun. 2017, 53, 889 .

[33] Xiao, T.; Feng, X.; Wang, Q.; Lin, C.; Wang, L.; Pan, Y. Chem. Commun. 2013, 49, 8329.

[34] Beijer, F. H.; Sijbesma, R. P.; Kooijman, H.; Spek, A. L.; Meijer, E. W. J. Am. Chem. Soc. 1998, 120, 6761.

[35] Sijbesma, R. P.; Beijer, F. H.; Brunsveld, L.; Folmer, B. J. B.; Hirschberg, J. H. K. K.; Lange, R. F. M.; Lowe, J. K. L.; Meijer, E. W. Science 1997, 278, 1601.

[36] Xiao, T.; Zhong, W.; Qi, L.; Gu, J.; Feng, X.; Yin, Y.; Li, Z.-Y.; Sun, X.-Q.; Cheng, M.; Wang, L. Polym. Chem. 2019, 10, 3342.
[37] Xiao, T.; Xu, L.; Wang, J.; Li, Z.-Y.; Sun, X.-Q.; Wang, L. Org. Chem. Front. 2019, 6, 936.

[38] Yan, X.; Liu, Z.; Zhang, Q.; Lopez, J.; Wang, H.; Wu, H. C.; Niu, S.; Yan, H.; Wang, S.; Lei, T.; Li, J.; Qi, D.; Huang, P.; Huang, J.; Zhang, Y.; Wang, Y.; Li, G.; Tok, J. B.; Chen, X.; Bao, Z. J. Am. Chem. Soc. 2018, 140, 5280.

[39] Song, Y.; Liu, Y.; Qi, T.; Li, G. L. Angew. Chem., Int. Ed. 2018, 57, 13838.

[40] Liu, M.; Liu, P.; Lu, G.; Xu, Z.; Yao, X. Angew. Chem., Int. Ed. 2018, 57, 11242 .

[41] Qin, B.; Zhang, S.; Song, Q.; Huang, Z.; Xu, J. F.; Zhang, X. Angew. Chem., Int. Ed. 2017, 56, 7639.

[42] Peng, H.-Q.; Zheng, X.; Han, T.; Kwok, R. T. K.; Lam, J. W. Y.; Huang, X.; Tang, B. Z. J. Am. Chem. Soc. 2017, 139, 10150

[43] Lavrenova, A.; Balkenende, D. W. R.; Sagara, Y.; Schrettl, S.; Simon, Y. C.; Weder, C. J. Am. Chem. Soc. 2017, 139, 4302.

[44] Peng, H.-Q.; Sun, C.-L.; Niu, L.-Y.; Chen, Y.-Z.; Wu, L.-Z.; Tung, C.-H.; Yang, Q.-Z. Adv. Funct. Mater. 2016, 26, 5483.

[45] Fu, X.; Gu, R.-R.; Zhang, Q.; Rao, S.-J.; Zheng, X.-L.; Qu, D.-H.; Tian, H. Polym. Chem. 2016, 7, 2166

[46] Xiao, T.; Xu, L.; Götz, J.; Cheng, M.; Wuerthner, F.; Gu, J.; Feng, X.; Li, Z.-Y.; Sun, X.; Wang, L. Mater. Chem. Front. 2019, 7, 1526-1540.

[47] Chen, J. Z.; Yan, X. Z.; Chi, X. D.; Wu, X. J.; Zhang, M. M.; Han, C. Y.; Hu, B. J.; Yu, Y. H.; Huang, F. H. Polym. Chem. 2012, 3, 3175 .

[48] Yan, X.; Zhou, M.; Chen, J.; Chi, X.; Dong, S.; Zhang, M.; Ding, X.; Yu, Y.; Shao, S.; Huang, F. Chem. Commun. 2011, 47, 7086.

[49] Zhang, C.; Li, S.; Zhang, J.; Zhu, K.; Li, N.; Huang, F. Org. Lett. 2007, 9, 5553 .

[50] Xu, L.; Shen, X.; Zhou, Z.; He, T.; Zhang, J.; Qiu, H.; Saha, M. L.; Yin, S.; Stang, P. J. J. Am. Chem. Soc. 2018, 140, 16920.

[51] Li, X.; Wang, L.; Deng, Y.; Luo, Z.; Zhang, Q.; Dong, S.; Han, C. Chem. Commun. 2018, 54, 12459.

[52] Zhang, M.; Yin, S.; Zhang, J.; Zhou, Z.; Saha, M. L.; Lu, C.; Stang, P. J. Proc. Natl. Acad. Sci. U. S. A. 2017, 114, 3044.

[53] Jiang, W.; Schäfer, A.; Mohr, P. C.; Schalley, C. A. J. Am. Chem. Soc. 2010, 132, 2309.

[54] Xiao, T. X.; Qi, L. J.; Zhong, W. W.; Lin, C.; Wang, R. B.; Wang, L. Y. Mater. Chem. Front. 2019, 3, 1973.

[55] Xiao, T.; Zhou, L.; Xu, L.; Zhong, W.; Zhao, W.; Sun, X.-Q.; Elmes, R. B. P. Chin. Chem. Lett. 2019, 30, 271.

[56] Xiao, T.; Zhong, W.; Zhou, L.; Xu, L.; Sun, X.-Q.; Elmes, R. B. P.; Hu, X.-Y.; Wang, L. Chin. Chem. Lett. 2019, 30, 31.

[57] Xiao, T.; Zhong, W.; Xu, L.; Sun, X.-Q.; Hu, X.-Y.; Wang, L. Org. Biomol. Chem. 2019, 17, 1336.

[58] Xiao, T.; Xu, L.; Zhou, L.; Sun, X.-Q.; Lin, C.; Wang, L. J. Mater. Chem. B 2019, 7, 1526.

[59] Xiao, T.; Wang, L. Tetrahedron Lett. 2018, 59, 1172.

[60] Yan, X.; Xu, D.; Chen, J.; Zhang, M.; Hu, B.; Yu, Y.; Huang, F. Polym. Chem. 2013, 4, 3312.

[61] Chen, Z.-Q.; Chen, T.; Liu, J.-X.; Zhang, G.-F.; Li, C.; Gong, W.-L.; Xiong, Z.-J.; Xie, N.-H.; Tang, B. Z.; Zhu, M.-Q. Macromolecules 2015, 48, 7823.

[62] Czech, A.; Czech, B. P.; Bartsch, R. A. J. Heterocycl. Chem. 1988, $25,1841$.

[63] Keizer, H. M.; Sijbesma, R. P.; Meijer, E. W. Eur. J. Org. Chem. 2004, 2553.

[64] Rao, M. L. N.; Dasgupta, P. Tetrahedron Lett. 2012, 53, 162.

(Lu, Y.) 